SOARES, D. A.; ANDEOTTI, M.; VICENT INI, M. E.; FREIT AS, L. A.; MODESTO, V. C.; NAKAO, A. H.; DICKMANN, L.; TEIXEIRAFILHO, M. C. M. Grain sorghum grown as second crop and inoculated with Azospirillum brasilense associated with nitrogen fertilization. Re vista de Agricultura Neotropical, Cassilândia-MS, v. 8, n. 3, e5117, jul./set. 2021. ISSN 2358-6303. DOI: https://doi.org/10.32404/rean.v8i3.5117.

\title{
Grain sorghum grown as second crop and inoculated with Azospirillum brasilense associated with nitrogen fertilization
}

\author{
Deyvison de Asevedo Soares ${ }^{1}$, Marcelo Andreotti ${ }^{1}$, Maria Elisa Vicentini ${ }^{2}$, Leandro Alves \\ Freitas $^{3}$, Viviane Cristina Modesto ${ }^{1}$, Allan Hisashi Nakao $^{4}$, Lourdes Dickmann ${ }^{1}$, Marcelo \\ Carvalho Minhoto Teixeira Filho ${ }^{1}$
}

\author{
${ }^{1}$ Universidade Estadual Paulista "Júlio de Mesquita Filho". Campus Ilha Solteira. Ilha Solteira. São Paulo. Brasil. E-mail: \\ dey vison.a.soares@.gmail.com, dreotti@agr.feis.unesp.br, vivimodesto12@gmail.com, lourdesdickmann@hotmail.com, \\ mcm.teixeira-filho@unesp.br \\ ${ }^{2}$ Universidade Estadual Paulista "Júlio de Mesquita Filho", Campus Jaboticabal, Jaboticabal, São Paulo, Brasil. E-mail: \\ mevicentini@gmail.com \\ ${ }^{3}$ Universidade Tecnológica Federal do Paraná, Campus Pato Branco, Pato Branco-Paraná, Brasil. E-mail: \\ leandroalvesfreitas@gmail.com \\ ${ }^{4}$ Centro Universitário de Santa Fé do Sul, Campus Santa Fé do Sul, Santa Fé do Sul, São Paulo, Brasil. E-mail: \\ allannakao@hotmail.com
}

Received: 05/06/2020; Accepted:24/05/2021.

\begin{abstract}
Nitrogen fertilization in off-season sorghum may have lower cost-benefit ratios than expected due to the residual effect of previous crops. However, the use of growth-promoting bacteria can be an economical alternative to increase crop yields in Cerrado. The objective was to evaluate the response of grain sorghum to nitrogen fertilization and its inoculation by Azospirillum brasilense. This study aims to evaluate grain sorghum responses to nitrogen fertilization and $A$. brasilense inoculation. The experiment was carried out in a fully randomized block design and $5 \times 2$ factorial scheme, with five replications. Treatments consisted of applying $\mathrm{N}$ recommendation $(120 \mathrm{~kg} \mathrm{~N}-\mathrm{urea}$ $\mathrm{ha}^{-1}$ ) split as follows: $100 \%$ at sowing, $100 \%$ as topdressing, $25 \%$ at sowing and $75 \%$ as topdressing, $50 \%$ at sowing and $50 \%$ as topdressing, and a control (without application), all these with and without A. brasilense seed inoculation. We also assessed the morphological and productivity components of grain sorghum. The application of $100 \% \mathrm{~N}$ at sowing promoted taller plants, while 50\% -50\% splitting shorter ones. Overall, grain sorghum plants did not respond to A. brasilense inoculation. Moreover, yield components of rainfed sorghum grown in succession to soybeans were not affected by A. brasilense inoculation and $\mathrm{N}$ supplied at once or split.
\end{abstract}

Keywords: Splitting, Crop succession, Sorghum bicolor, PGPB.

\section{Sorgo granífero em segunda safra inoculado com Azospirillum brasilense associado a adubação nitrogenada}

\section{RESUMO}

As atuais recomendações de $\mathrm{N}$ para o sorgo segunda safra, em plantio direto, podemser ineficientes devido a fatores técnicos e edafoclimáticos. Assim, a inoculação por Azospirillum brasilense tem sido estudada como uma alternativa econômica para suprir $\mathrm{N}$ à cultura no Cerrado. Avaliou-se a resposta do sorgo granífero à adubação nitrogenada associada a inoculação com A. brasilense. O delineamento experimental foi em blocos casualizados, em esquema fatorial $5 \times 2$, com cinco repetições dos seguintes tratamentos: quantidade recomendada de $\mathrm{N}$ (120 kg ha $^{-1}$ de N-ureia) aplicada $100 \%$ na semeadura, ou apenas em cobertura, ou parcelada - $25 \%$ na semeadura e $75 \%$ na cobertura, ou $50 \%$ na semeadura e $50 \%$ na cobertura, e o controle (sem N); come sem inoculação via semente do sorgo. Foram avaliados os componentes morfológicos e de produtividade da cultura. A aplicação de $100 \%$ do $\mathrm{N}$ na semeadura proporcionou plantas com porte maior e o parcelamento $50 \%-50 \%$ proporcionou plantas de menor porte. As plantas não res ponderam à inoculação por A. brasilense. Os componentes de produção do sorgo cultivado em sucessão à soja, em sequeiro, não se alteram devido à inoculação por A. brasilense e ao fornecimento ou parcelamento da adubação nitrogenada.

Palavras-chave: Parcelamento, Sucessão de culturas, Sorghum bicolor, BPCP. 


\section{Introduction}

Off-season grain sorghum is more efficient than other grain crops such as corn and wheat as for water-to-dry matter conversion (Magalhães et al., 2015), which occurs due to biochemical and morphological mechanisms making plants more drought tolerant. Therefore, including sorghum in crop rotation/succession becomes relevant in no-tillage systems (NTS) in the Brazilian Cerrado. Indeed, NTS consolidation and success is due to the use of straw-producing plants at proper amounts for soil covering (Andreotti et al., 2008), combined with suitable nutritional management and other cultural treatments.

Sorghum responses to nitrogen (N) fertilization depend on previous crops and may range from high and medium to low (Cantarella et al., 1997). Besides identifying its responsiveness, suitable amount and timing for mineral $\mathrm{N}$ application are also relevant for decision-making by farmers.

As a rule, succession between legume and nonlegume crops has a good effect (Mascarenhas et al., 2011). According to Arif et al. (2011), corn crops perform better when grown with residue from chickpeas if compared to residue from other grains. This is due to the low $\mathrm{C} / \mathrm{N}$ ratio of legume residues that mineralize quickly and can release $\mathrm{N}$, meeting the demand for subsequent crops (Odhiambo, 2010). In this sense, many farmers do not fertilize crops and only sow on residues from previous crops (usually soybeans). This practice is based on the promotion of atmospheric $\mathrm{N}$ fixation by legumes, relatively speeding up $\mathrm{N}$ cycling given fast decomposition and mineralization of low $\mathrm{C} / \mathrm{N}$ ratio residues (Veras et al., 2016). Mineralization is rapid due to the high $\mathrm{N}$ rates and low lignin and polyphenol contents in the residue (Abera et al., 2012).

Conversely, the use of nitrogen fertilizers in sorghum crops is deemed to be reduced when compared to demands of crops of great tradition and economic interest in Brazil. Moreover, the high cost of nitrogen fertilizers has driven research into natural $\mathrm{N}$ fixation and plant growth-promoting bacteria (PGPB) studies, as these supply all or part of the $\mathrm{N}$ demanded by crops or help absorb nutrients at low cost and less environmental impact (Hungria, 2011). In this context, studies on Azospirillum brasilense inoculation in grasses have exhibited several benefits to host plants, such as morphological and nutritional changes, increase in crop yield, among others (Longhini et al., 2016; Nakao et al., 2018).

Benefits of Azospirillum-host plant interactions have been reported as results frombiological nitrogen fixation (BNF) by colonizing bacteria. However, the symbiosis with rhizobacteria can produce plant growth-promoting substances (Bhattacharjee et al., 2008) such as auxins, cytokinins, and gibberellins (Ona et al., 2003; Cassán et al., 2009). Both mechanisms can occur simultaneously. However, once the efficiency of $A$. brasilense inoculation in plants can be influenced by several environmental, technical, and crop-intrinsic factors, further studies are still needed to evaluate such interactions under different environmental conditions.

In this study, we hypothesized that offseason sorghum under rainfed conditions and after soybean cultivation, grown on a clayey soil of medium fertility, dispense with $\mathrm{N}$ fertilization due to residual effects of the legume, and that, under these conditions, seed inoculation with $A$. brasilense improves sorghum development and yield. Therefore, our study aimed to evaluate grain sorghum performance in response to $\mathrm{N}$ fertilization splitting and $A$. brasilense seed inoculation.

\section{Material and Methods}

The current experiment was conducted at the Teaching, Research and Extension Farm of the College of Engineering of Ilha Solteira. The site is in the city of Selvíria, Mato Grosso do Sul State, Brazil (20 $18^{\prime} \mathrm{S}, 51^{\circ}$ $22^{\prime} \mathrm{W}, 370 \mathrm{~m}$ above sea level) (Figure 1). The experiment was conducted during the 2016 off-season under rainfed conditions. According to Köppen's classification, the local climate is classified as $A w$. Figure 2 shows the climate data gathered throughout the experiment.

According to Santos et al. (2018), the soil in the studied area is classified as clayey Red Latosol (Oxisol). Before the experiment, a grain-size analysis was performed ( 0.0 to $0.20 \mathrm{~m}$ depth) by the pipette method (Embrapa, 1997), and the results were as follows: 480, 175 , and $345 \mathrm{~g} \mathrm{~kg}^{-1}$ clay, silt, and sand fractions, respectively. Soil fertility was analyzed in the layers from 0.00 to 0.10 and from 0.10 to $0.20 \mathrm{~m}$, following Raij et al. (2001) (Table 1).

The experimental area had been cultivated under a no-tillage system (NTS) for five years. In the 2016 agricultural year, grain sorghum was grown (autumn/ winter) in succession to soybeans (spring/ summer). Fifteen days before the experiment, weeds were killed by the application of glyphosate $\left(1.44 \mathrm{~kg}\right.$ a.i. ha- $\left.{ }^{-1}\right)$, and plant residues ground using a horizontal mill (Triton).

The experimental design was randomized blocks and a 5 x 2 factorial scheme, with five replications. Treatments comprised $0 \% \mathrm{~N}$ at sowing and $100 \%$ as topdressing, 25\% at sowing and $75 \%$ as topdres sing, $50 \%$ at sowing and $50 \%$ as topdressing, $100 \%$ at sowing and $0 \%$ as topdressing, and a control (no $\mathrm{N}$ application), all with and without sorghum seed inoculation with A. brasilense. The fertilization was done manually and followed the recommended dose of $120 \mathrm{~kg} \mathrm{ha}^{-1} \mathrm{~N}$, using urea as a source. 


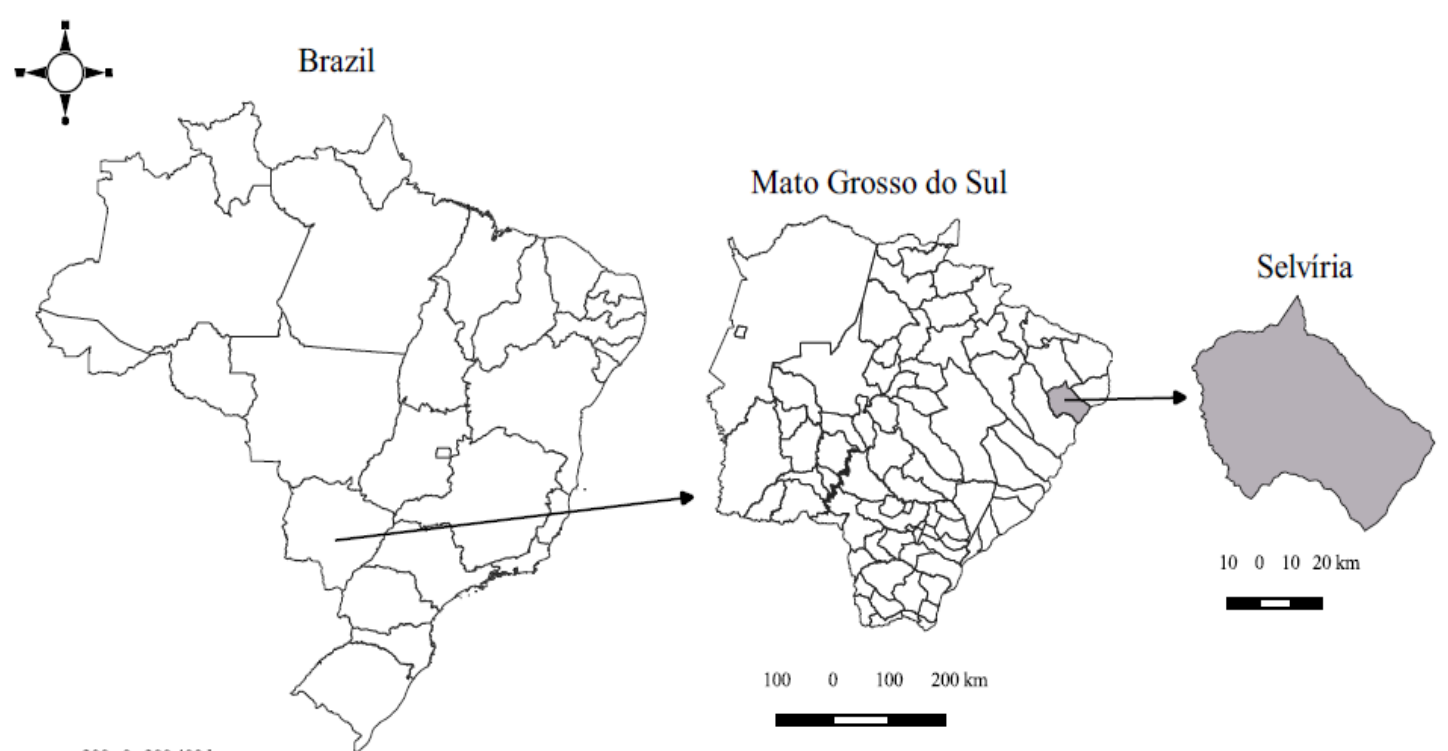

$200 \quad 0200400 \mathrm{~km}$

Figure 1 - Location of the experimental area. Selvíria city (MS), Brazil, 2016. SIRGAS 2000, Cartographic Bases (IBGE, 2020).

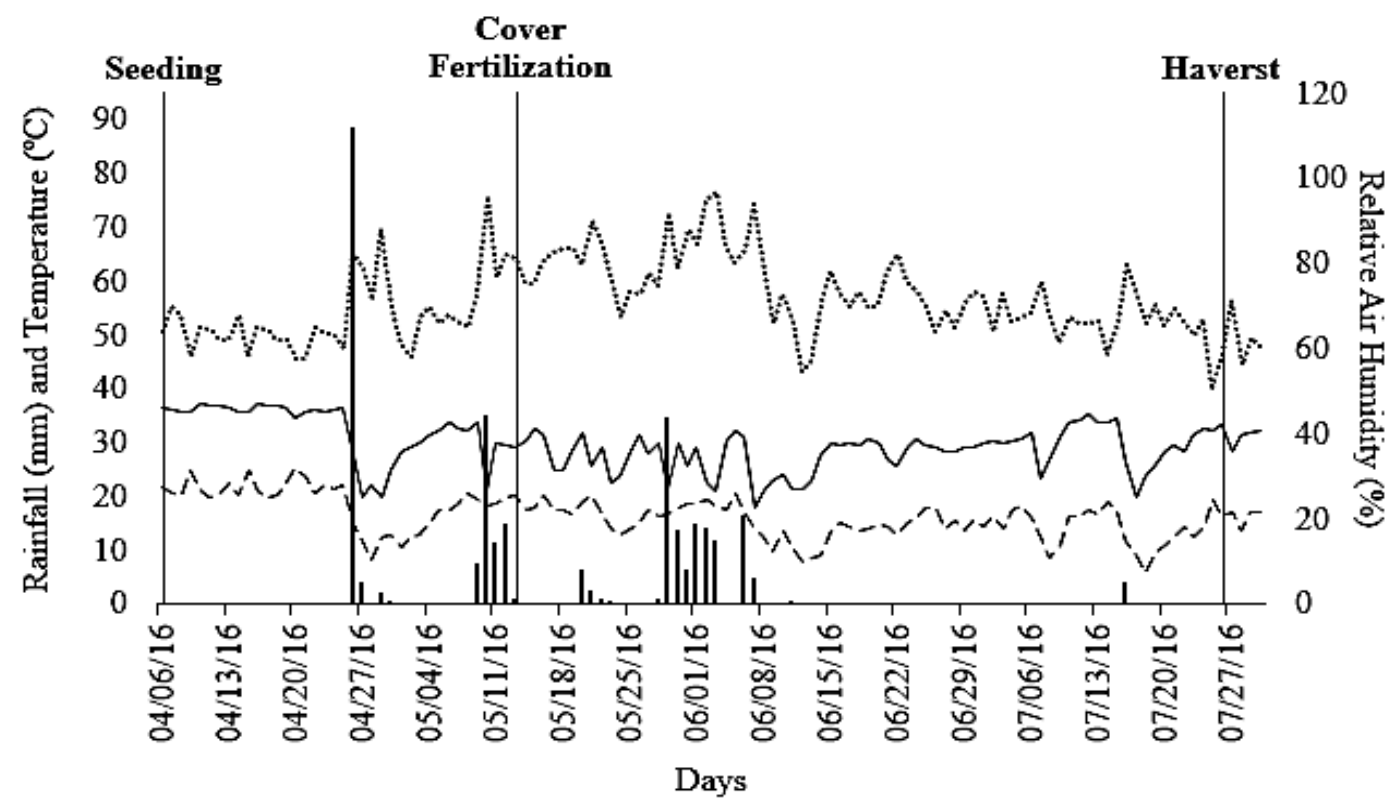

\section{Total Rainfall (mm) \\ $---\cdot$ Minimum Temperature $\left({ }^{\circ} \mathrm{C}\right)$ \\ - Máximum Temperature $\left({ }^{\circ} \mathrm{C}\right)$ \\ .......... Relative Air Humidity (\%)}

Figure 2 - Daily meteorological data of rainfall $(\mathrm{mm})$, maximum and minimum temperatures $\left({ }^{\circ} \mathrm{C}\right)$, and relative air humidity $(\%)$ during the experimental period. Selvíria - MS, Brazil, 2016.

Table 1. Soil chemical properties before sorghum sowing in Selvíria - MS, Brazil, 2016.

\begin{tabular}{|c|c|c|c|c|c|c|c|c|c|c|c|}
\hline Depth & resin $\mathrm{P}$ & $\mathrm{OM}$ & $\mathrm{pH}$ & $\mathrm{K}$ & $\mathrm{Ca}$ & $\mathrm{Mg}$ & $\mathrm{H}+\mathrm{Al}$ & $\mathrm{Al}$ & SB & CEC & $\mathrm{V}$ \\
\hline (m) & $\left(\mathrm{mg} \mathrm{dm}^{-3}\right)$ & $\left(\mathrm{g} \mathrm{dm}^{-3}\right)$ & $\left(\mathrm{CaCl}_{2}\right)$ & \multicolumn{5}{|c|}{$\left(\mathrm{cmol}_{\mathrm{c}} \mathrm{dm}^{-3}\right)_{-}$} & & & $(\%)$ \\
\hline $0.00-0.10$ & 27 & 23.0 & 5.4 & 0.4 & 2.0 & 1.6 & 3.6 & 0.0 & 4.0 & 7.5 & 51 \\
\hline $0.10-0.20$ & 18 & 19.4 & 5.1 & 0.3 & 1.5 & 1.0 & 3.9 & 0.1 & 2.7 & 6.6 & 40 \\
\hline
\end{tabular}


The hybrid sorghum 'Ranchero' was mechanically sown on April 6, 2016, under NTS, and spaced $0.45 \mathrm{~m}$ between rows. Sowing fertilization consisted of $90 \mathrm{~kg}$ $\mathrm{P}_{2} \mathrm{O}_{5}$ and $30 \mathrm{~kg} \mathrm{~K} \mathrm{~K}_{2} \mathrm{O}$, using simple superphosphate and potassium chloride as sources, respectively. Topdressing was done at the early panicle emergence (2-GS2 growth stage) when plants were around $0.30 \mathrm{~m}$ tall (May 13, 2016).

Experimental plots comprised seven 6-m-long and 3.15-m-wide sowing rows $\left(22.05 \mathrm{~m}^{2}\right)$. Only the three central rows composed the useful area, disregarding 1.5 $m$ from the ends of each row. The hybrid 'Ranchero' was used since it has an aptitude for grain production. Diazotrophic bacteria were supplied by the AzoTotal ${ }^{\mathrm{TM}}$ inoculant, which was developed for corn and wheat crops (under registration number PR-93923-10074-1 by the Brazilian Ministry of Agriculture). It has a liquid physical nature, a density of $1.0 \mathrm{~g} \mathrm{~mL}^{-1}$, and a dose of 100 $\mathrm{mL}$ per $20 \mathrm{~kg}$ seeds (containing $2 \times 10^{8}$ colony forming units CFUs per $\mathrm{mL}$ of A. brasilense, AbV5 and AbV6 strains). Sorghum seeds were inoculated about 30 minutes before sowing under shade.

Nitrogen topdressing was performed manually by applying fertilizer at $10 \mathrm{~cm}$ from sorghum plants as a function of each treatment, at about 30 days after emergence (DAE) when plants were about $0.30 \mathrm{~m}$ high (13/05/2016) at panicle initiation stage (GS2).

At harvest time (July 26, 2016), the final plant stand (FPS) was determined by counting plants within 3 central rows of each plot, discarding $1.5 \mathrm{~m}$ from each end. For evaluations, 10 plants were randomly collected from each useful area, and the following parameters were determined: stem basal diameter (SBD), plant height $(\mathrm{PH})$, panicle insertion height $(\mathrm{PIH})$, panicle length $(\mathrm{PL})$, total plant dry matter (TPDM), panicle dry matter $(\mathrm{PaDM})$, grain mass per panicle (GMP), grain number per panicle (GNP), and rates of stem, leaf, and panicle dry matter in relation to TPDM. These fractions were separated with the aid of pruning shears and then weighed and dried in an oven $\left(65^{\circ} \mathrm{C}\right)$ to determine dry matter and harvest index (ratio between grain dry matter (GDM) and TPDM). One thousand grain mass (TGM) was determined by weighing four subsamples per plot and corrected for $13 \%$ moisture.

All data underwent Shapiro-Wilk's test of normality. Afterwards, data were analyzed by F-test $(\mathrm{p}<0.05)$, and the means compared by Tukey's test $(\mathrm{p}<0.05)$ using SISVAR 5.7 software (Ferreira, 2019).

\section{Results and Discussion}

There was no significant interaction between inoculation and nitrogen splitting for the studied parameters ( $p>0.05$ ). Many studies have reported the benefits of Azospirillum-plant interactions (Longhini et al., 2016; Nakao et al., 2018). However, plant responses to inoculation can be influenced by cropping conditions such as soil $\mathrm{pH}$, temperature, and humidity (Cardoso et al., 2010; Hungary, 2011). These factors proved to be limiting for bacteria due to climatic conditions (Figure 2) during sorghum crop implantation.

Nitrogen splits significantly affected $(\mathrm{p}<0.05)$ plant (PH) and panicle insertion (PIH) heights of sorghum plants. Fractional fertilization of $50 \%$ at sowing and $50 \%$ as topdressing reduces $\mathrm{PH}$ and $\mathrm{PIH}$ compared to $100 \%$ at sowing. The other treatments did not differ from each other (Table 2). Short sorghum plants facilitate mechanized grain harvesting and reduce risks of lodging, increasing final yields (Pereira Filho and Rodrigues, 2015). However, the highest PH (1.4 m) when applying $100 \%$ at sowing does not cause lodging. Molina et al. (2000) observed barely any (0\%) lodging losses in sorghum plants between 1.0 to $1.5 \mathrm{~m}$ high, which is common in grain sorghum hybrids.

The significant response of sorghum to $100 \% \mathrm{~N}$ fertilization at sowing (Table 2) can be justified both by its larger demand in early growth and intense nutrient uptake between 20 to 30 DAE (7 to 12 fully developed leaves) (Coelho et al., 2002). As regards the clayey soil texture, it contributed to lower $\mathrm{N}$ losses from mineral fertilizers (Tahir and Marschner, 2017). Another time of high nutritional demand for sorghum is the grain-forming stage (Coelho et al., 2002), which is when roots are well developed and explore efficiently the soil volume. Therefore, the absence of $\mathrm{N}$ topdressing (100\%- $0 \%$ ) may have been supplied by organic matter in the soil $\left(23.0 \mathrm{~g} \mathrm{dm}^{-3}\right)$, contributing greatly to $\mathrm{N}$ availability in soil solution by mineralization (Lorensini et al., 2014).

Averages of panicle dry matter (PaDM), grain dry matter (GDM), and total plant dry matter (TPDM) were not influenced by the interaction between inoculation and splitting forms $(p>0.05)$. According to Macedo et al. (2018), sorghum PH is generally related to PDM, which was not observed in our study (Table 2 and Table 3). Such results corroborate the previously mentioned hypothesis in which sorghum grown in a mediumfertility clayey soil, in succession to soybean cultivation, does not require $\mathrm{N}$ fertilization due to legume residual effects. Although it is an off-season crop, grain yield reached suitable values for the season (5.5 to $6.4 \mathrm{t} \mathrm{ha}^{-1}$; Table 3), according to Freitas et al. (2014).

Under favorable climatic conditions, well-managed commercial crops, mainly nutrient supply and disease control, can reach sorghum crop yields between 6 and 8 $\mathrm{t}$ grain ha-1 during the off-season (Resende et al., 2009). These yields can also be met even in the Cerrado, where there is less water availability for crops in the off-season (usually after soybeans). This is due to the well-fertilized soils, planting of improved cultivars, and use of technologies for general crop management. 
Table 2. Averages of final plant stand (FPS), stem basal diameter (SBD), plant height (PH), panicle insertion height (PIH), and panicle length (PL) of grain sorghum plants under nitrogen fertilization splitting followed by their respective standard errors.

\begin{tabular}{llllll}
\hline Treatment & FPS & SBD & PH & PIH & PL \\
\hline Inoculation (I) & $\left(\right.$ plants ha $\left.^{-1}\right)$ & $(\mathrm{mm})$ & $(\mathrm{m})$ & $(\mathrm{m})$ & $(\mathrm{cm})$ \\
Without & $191,605 \pm 6,160$ & $17 \pm 0.3$ & $1.3 \pm 0.01$ & $1.1 \pm 0.01$ & $26 \pm 0.4$ \\
With & $175,309 \pm 7,473$ & $17 \pm 0.3$ & $1.2 \pm 0.02$ & $1.0 \pm 0.02$ & $27 \pm 0.3$ \\
N splitting (S) $^{1}$ & & & & \\
$0 \%-100 \%$ & $177,778 \pm 8,226$ & $17 \pm 0.4$ & $1.3 \pm 0.02 \mathrm{ab}$ & $1.0 \pm 0.02 \mathrm{ab}$ & $26 \pm 0.5$ \\
$25 \%-75 \%$ & $173,827 \pm 10,018$ & $17 \pm 0.3$ & $1.3 \pm 0.02 \mathrm{ab}$ & $1.0 \pm 0.03 \mathrm{ab}$ & $27 \pm 0.2$ \\
$50 \%-50 \%$ & $162,469 \pm 7,706$ & $17 \pm 0.3$ & $1.2 \pm 0.01 \mathrm{~b}$ & $0.9 \pm 0.02 \mathrm{~b}$ & $27 \pm 0.7$ \\
$100 \%-0 \%$ & $188,148 \pm 12,648$ & $17 \pm 0.6$ & $1.4 \pm 0.02 \mathrm{a}$ & $1.1 \pm 0.02 \mathrm{a}$ & $26 \pm 0.4$ \\
Control & $194,074 \pm 15,472$ & $16 \pm 0.7$ & $1.3 \pm 0.03 \mathrm{ab}$ & $1.0 \pm 0.04 \mathrm{ab}$ & $26 \pm 0.8$ \\
\hline & $\mathrm{p}-\mathrm{values}$ & & & \\
\hline I & $0.0904^{\text {ns }}$ & $0.7152^{\text {ns }}$ & $0.3103^{\text {ns }}$ & $0.1824^{\text {ns }}$ & $0.0852^{\text {ns }}$ \\
S & $0.2006^{\text {ns }}$ & $0.7386^{\text {ns }}$ & $0.0490^{*}$ & $0.0348^{*}$ & $0.2019^{\text {ns }}$ \\
I x S & $0.1008^{\text {ns }}$ & $0.3323^{\text {ns }}$ & $0.1253^{\text {ns }}$ & $0.1533^{\text {ns }}$ & $0.1073^{\text {ns }}$ \\
CV \% & 12 & 6 & 4 & 4 & 4 \\
\hline
\end{tabular}

Means followed by different letters differ from each other by Tukey's test at $5 \%$ probability. 'at sowing and as topdressing, respectively; *: $p<0.05$; ns: non-significant by Tukey's test ( $>>0.05)$; CV \%: coefficient of variation

Table 3. Averages of plant dry matter (PDM), panicle dry matter (PaDM), yield dry matter (YDM), grain yield (YP), harvest index (HI) of grain sorghum under $\mathrm{N}$ fertilization splitting, followed by their respective standard errors.

\begin{tabular}{|c|c|c|c|c|c|}
\hline Treatment & $\overline{P D M}$ & PaDM & YDM & GY & HI \\
\hline Inoculation (I) & $(\mathrm{g})_{-}$ & & $\left(\mathrm{Mgha}^{-1}\right)$ & $\left(\mathrm{kg} \mathrm{ha}^{-1}\right)$ & - \\
\hline Without & $64.4 \pm 5.35$ & $38 \pm 3$ & $13.3 \pm 0.66$ & $6,055 \pm 251$ & $0.47 \pm 0.04$ \\
\hline With & $57.8 \pm 3.01$ & $32 \pm 2$ & $12.9 \pm 0.39$ & $6,183 \pm 186$ & $0.50 \pm 0.02$ \\
\hline \multicolumn{6}{|l|}{$\mathrm{N}$ splitting $(\mathrm{S})^{1}$} \\
\hline $0 \%-100 \%$ & $66.2 \pm 8.31$ & $36 \pm 4$ & $14.1 \pm 1.04$ & $5,994 \pm 297$ & $0.44 \pm 0.04$ \\
\hline $25 \%-75 \%$ & $66.4 \pm 7.30$ & $36 \pm 5$ & $12.1 \pm 0.90$ & $6,385 \pm 170$ & $0.49 \pm 0.07$ \\
\hline $50 \%-50 \%$ & $67.1 \pm 8.21$ & $37 \pm 4$ & $13.7 \pm 0.42$ & $5,974 \pm 374$ & $0.46 \pm 0.04$ \\
\hline $100 \%-0 \%$ & $59.1 \pm 3.25$ & $34 \pm 3$ & $12.6 \pm 0.82$ & $6,334 \pm 416$ & $0.51 \pm 0.05$ \\
\hline \multirow[t]{2}{*}{ Control } & $58.7 \pm 8.14$ & $39 \pm 4$ & $12.8 \pm 0.32$ & $5,472 \pm 253$ & $0.39 \pm 0.03$ \\
\hline & p-values & & & & \\
\hline I & $0.3525^{\mathrm{ns}}$ & $0.0564^{\mathrm{ns}}$ & $0.6587^{\mathrm{nS}}$ & $0.6869^{\mathrm{nS}}$ & $0.6204^{\mathrm{ns}}$ \\
\hline S & $0.8579^{\mathrm{ns}}$ & $0.9430^{\mathrm{ns}}$ & $0.3677^{\mathrm{ns}}$ & $0.3367^{\mathrm{ns}}$ & $0.4874^{\mathrm{ns}}$ \\
\hline I $x \mathrm{~S}$ & $0.3512^{\mathrm{ns}}$ & $0.5513^{\text {ns }}$ & $0.3535^{\mathrm{ns}}$ & $0.4865^{\mathrm{ns}}$ & $0.7441^{\mathrm{ns}}$ \\
\hline C.V. $\%$ & 24 & 25 & 13 & 12 & 23 \\
\hline
\end{tabular}

${ }^{\mathrm{T}}$ At sowing and as topdressing, respectively; CV \%: coefficient of variation; ns: non-significant by Tukey's test (p>0.05).

The above-mentioned results reflected in the harvest index (HI), which was similar in all $\mathrm{N}$-splitting forms (Table 3). This factor is adequate, and although the control had a lower HI, we assume that it is not due to treatment $(p>0.05)$. The index measures genotype efficiency in translocating photoassimilates to grains, and might be negatively influenced by environmental adversities such as water and nutrient availability and temperature (Pereira Filho and Rodrigues, 2015). Such conditions were not limiting for sorghum development in our study. Crop productivity components were not significantly influenced by inoculation and $\mathrm{N}$-fertilization splitting interaction $(p>0.05)$. Percentages of plant and reproductive sorghum components showed no significant differences. These parameters were not dependent on inoculation and fertilizer application or even respective splitting (Table 4).

Notably, even control(without $\mathrm{N}$ fertilization) showed no significant differences for the productivity parameters ( $>$ > 0.05) compared to fertilizer treatments (Tables 2, 3, and 4). It may be due to soybean residues with a low $\mathrm{C}: \mathrm{N}$ ratio, providing sorghum high quality (Odhiambo, 2010). Indeed, low lignin and polyphenol contents speed up decomposition and nutrient cycling (Carvalho et al., 2010) for crops sown in succession. 
Table 4. Averages of grain mass per panicle (GMPa); one thousand grain mass (TGM); number of grains per panicle (NGP); and percentages of stems $(\mathrm{S} \%)$, leaves $(\mathrm{L} \%)$, and panicle $(\mathrm{P} \%)$ for grain sorghum under nitrogen fertilization splitting and their respective standard errors.

\begin{tabular}{|c|c|c|c|c|c|c|}
\hline Treatment & GMPa & TGM & NGP & S\% & $\mathrm{L} \%$ & $\mathrm{P} \%$ \\
\hline Inoculation (I) & $(\mathrm{g})$ & & - & \multicolumn{2}{|c|}{$-(\%)$} & \\
\hline Without & $32 \pm 2$ & $24 \pm 1$ & $1,387 \pm 73$ & $32 \pm 1$ & $14 \pm 1$ & $54 \pm 1$ \\
\hline With & $29 \pm 2$ & $24 \pm 1$ & $1,230 \pm 74$ & $31 \pm 1$ & $14 \pm 1$ & $55 \pm 1$ \\
\hline \multicolumn{7}{|l|}{${\underline{\mathrm{N}} \text { splitting }(\mathrm{S})^{1}}^{1}$} \\
\hline $0 \%-100 \%$ & $28 \pm 1$ & $23 \pm 1$ & $1,212 \pm 69$ & $32 \pm 2$ & $13 \pm 1$ & $55 \pm 2$ \\
\hline $25 \%-75 \%$ & $31 \pm 5$ & $25 \pm 1$ & $1,233 \pm 183$ & $31 \pm 1$ & $13 \pm 1$ & $55 \pm 2$ \\
\hline $50 \%-50 \%$ & $30 \pm 2$ & $23 \pm 2$ & $1,314 \pm 130$ & $30 \pm 2$ & $14 \pm 1$ & $56 \pm 1$ \\
\hline $100 \%-0 \%$ & $32 \pm 3$ & $24 \pm 1$ & $1,356 \pm 143$ & $32 \pm 2$ & $14 \pm 1$ & $54 \pm 2$ \\
\hline \multirow[t]{2}{*}{ Control } & $27 \pm 5$ & $24 \pm 1$ & $1,141 \pm 100$ & $29 \pm 1$ & $14 \pm 1$ & $57 \pm 2$ \\
\hline & p-values & & & & & \\
\hline I & $0.2162^{\mathrm{ns}}$ & $0.7377^{\mathrm{ns}}$ & $0.1446^{\mathrm{ns}}$ & $0.5535^{\mathrm{ns}}$ & $0.6185^{\mathrm{ns}}$ & $0.4856^{\mathrm{ns}}$ \\
\hline S & $0.5979^{\mathrm{ns}}$ & $0.8731^{\mathrm{ns}}$ & $0.7632^{\mathrm{ns}}$ & $0.6178^{\mathrm{ns}}$ & $0.9165^{\mathrm{ns}}$ & $0.6398^{\mathrm{ns}}$ \\
\hline $\mathrm{I} \times \mathrm{S}$ & $0.3537^{\mathrm{ns}}$ & $0.5891^{\mathrm{ns}}$ & $0.2110^{\mathrm{ns}}$ & $0.5784^{\mathrm{ns}}$ & $0.9585^{\mathrm{ns}}$ & $0.5714^{\mathrm{ns}}$ \\
\hline $\mathrm{CV} \%$ & 19 & 12 & 17 & 11 & 13 & 6 \\
\hline
\end{tabular}

${ }^{\mathrm{T}}$ At sowing and as topdressing, respectively; C.V. \%: Coefficient of Variation; ns: non-significant by Tukey's test (p>0.05).

According to Mateus et al. (2011), no-tillage crop rotation systems, besides permanent soil cover, cycle nutrients in residues and increase soil $\mathrm{N}$ supply for the next crop. Crusciol et al. (2011) reported that soil $\mathrm{N}$ supply is mostly due to constant use of $\mathrm{N}$ fertilizers in crops comprising the rotation/succession systems, besides $\mathrm{N}$ mineralization in high-quality and low $\mathrm{C}: \mathrm{N}$ ratio plant residues.

The foregoing suggests that regardless of $\mathrm{N}$ fertilization or its splitting, soybean residues in soil increased sorghum yield components in succession. Accordingly, the lack of sorghum response to N splitting may be related to previous NT crops in the experimental area (Table 1). Another factor would be the low rainfall rates during the experiment (Figure 2), which, although occurred, did not limit sorghum yield potential, reflected in suitable grain yields (Freitas et al., 2014) that was equivalent among all treatments.

It should also be emphasized that $\mathrm{N}$ dynamics in the soil-plant-air system is complex. $\mathrm{N}$ efficiency depends on several factors interacting simultaneously such as cropping system, $\mathrm{N}$ application amount and timing, plant residues from previous crops, and edaphoclimatic factors acting on $\mathrm{N}$ volatilization, leaching, mobilization or nonmobilization (Farinelli and Lemos, 2010, Lorensini et al., 2012, Silva et al., 2017, Ajeigbe et al., 2018).

Although soil texture may improve $\mathrm{N}$-fertilizer maintenance without significant leaching losses, climatic conditions and fertilizer nature must have been considered to evaluate our results. This is because, after soil application, urea is hydrolyzed by urease to form ammonium carbonate $\left[\mathrm{CO}\left(\mathrm{NH}_{2}\right)_{2}+2 \mathrm{H}_{2} \mathrm{O} \rightarrow\right.$ $\left(\mathrm{NH}_{4}\right)_{2} \mathrm{CO}_{3}$ ], which decomposes rapidly to ammonium, hydroxyl, and bicarbonate $\left[\left(\mathrm{NH}_{4}\right)_{2} \mathrm{CO}_{3}+\mathrm{H}_{2} \mathrm{O} \rightarrow\right.$ $2 \mathrm{NH}_{4}^{+}+\mathrm{OH}^{-}+\mathrm{HCO}_{3}^{-}$, increasing $\mathrm{pH}$ around fertilizer granules (Rochette et al., 2009). In short, if urea is not incorporated into the soil, as in this study, part of the $\mathrm{NH}_{4}{ }^{+}$can convert to $\mathrm{NH}_{3}$ and be lost to the atmosphere (Nascimento et al., 2013; Rochette et al., 2013; Degaspari et al., 2020; Soares et al., 2020).

Ammonia volatilization from urea on the soil surface can be low, totaling $1 \%$, or extremely high, above $50 \%$ of the applied N (Cantarella et al., 2008; Sanz-Cobena et al., 2012; Tasca et al., 2011; Rochette et al., 2013). When high $\mathrm{N}$ doses are applied, losses can be greater (Ma et al., 2010) when soil moisture for infiltration is low and temperatures are high, as well as a greater amount of vegetation cover on the soil surface (Tasca et al., 2011; Nascimento et al., 2013; Liu et al. 2019; Degaspari et al., 2020; Soares et al., 2020), as observed in the present study.

\section{Conclusions}

The grain sorghum hybrid 'Ranchero', when grown in the off-season and succession to soybeans, and under water restriction, does not respond to Azospirillum brasilense inoculation and nitrogen fertilization. Furthermore, nitrogen splitting does not affect sorghum crop morphological components or grain yield. Application of half the recommended nitrogen dose at sowing and the other half as topdressing provides shortstature plants, without reducing dry matter production.

\section{Authors' Contribution}

Deyvison de Asevedo Soares contributed to the installation of the experiment, data collection, statistical analysis and writing of the article. Marcelo Andreotti was the first author's advisor, contributing to the statistical 
analysis and advising on the writing and correction of the article. Maria Elisa Vicentini contributed to the implementation of the experiment, data collection, correction of the article and creating the Figure 1. Leandro Alves Freitas contributed to the implementation of the experiment, data collection, advice on the writing and correction of the article.

Viviane Cristina Modesto contributed to the installation of the experiment, data collection and translation of the article. Allan Hisashi Nakao contributed to the installation of the experiment, data collection. Lourdes Dickmann contributed to the installation of the experiment and data collection. Marcelo Carvalho Minhoto Teixeira Filho was the first author's co-advisor, advising on the writing and correction of the article.

\section{Acknowledgments}

To the National Council for Scientific and Technological Development (CNPq) and São Paulo State University-UNESP, Ilha Solteira.

\section{Bibliographic References}

Abera, G., Wolde-Meskel, E., Bakken, L.R. 2012. Carbon and nitrogen mineralization dynamics in different soils of the tropics amended with legume residues and contrasting soil moisture contents. Biology and Fertility of Soils, 48(1), 5166. DOI: https://doi.org/10.1007/s00374-011-0607-8

Ajeigbe. H.A.. Akinseve. F.M.. Avuba. K.. Jonah. J. 2018. Productivity and water use efficiency of sorghum [Sorghum bicolor (L.) Moench] grown under different nitrogen applications in Sudan Savanna zone, Nigeria. International Journal of Agronomy, 2018(767605), 1-11. DOI: https://doi.org/10.1155/2018/7676058

Andreotti, M., Araldi, M., Guimarães, V.F., Furlani Junior, E., Buzetti, S. 2008. Produtividade do milho safrinha e modificações químicas de um Latossolo em sistema plantio direto em função de espécies de cobertura após calagem superficial. Acta Scientiarum Agronomv. 1(1). 109-115. DOI: http://dx.doi.org/10.4025/actasciagron.v30i1.1158

Arif, M., Jan, M.T., Khan, M.J., Saeed, M., Munir, I., Ziauddin, Akbar, H., Shahenshah, Khan, M.Z. 2011. Effect of cropping system and residue management on maize. Pakistan Journal of Botanv. 43(2). 915-920. https://www.pakbs.org/pjbot/PDFs/43(2)/PJB43(2)0915.pdf (accessed May 31, 2021)

Bhattacharjee, R.B., Singh, A., Mukhopadhy ay, S.N. 2008. Use of nitrogen-fixing bacteria as biofertiliser for non-legumes: prospects and challenges. Applied Microbiology Biotechnologv. $80 . \quad 199-209 . \quad$ DOI: https://doi.org/10.1007/s00253-008-1567-2

Cantarella, H., Raij, B.V., Camargo, C.E.O. 1997. Cereais, in: Raij, B.V., Cantarella, H., Quaggio, J.A., Furlani, A.M.C. (Ed.)
Recomendações de calagem e adubação para o Estado de São Paulo. Instituto Agronômico de Campinas, Campinas. http://www.etecsaosimao.com.br/_documentos/_pdf/_apoio_a o_aluno/_livros/BOLETIM_100_IAC_Completo.pdf (accessed May 31, 2021)

Cantarella. H.. Trivelim. P.C.O.. Contin. T.L.M.. Dias. F.L.F. Rossetto, R., Marcelino, R., Coimbra, R.B., Quaggio, J.A. 2008. Ammonia volatilisation from urease inhibitor-treated urea applied to sugarcane trash blankets. Scientia Agricola, 65(4), 397-401. DOI: https://doi.org/10.1590/S010390162008000400011

Cardoso, I.C.M., Klauberg Filho, O., M ariotto, J.R., Miquelluti, D.J., Vicente, D., Neves, A.N. 2010. Ocorrência de bactérias endofíticas do gênero Azospirillum em arroz irrigado no estado de Santa Catarina. Revista de Ciências Agroveterinárias, 9(2), 178-186. https://www.researchgate.net/publication/282646502 (accessed May 31, 2021)

Carvalho, A.M., Dantas, R. de A., Coelho, M.C., Lima, W.M., Souza, J.P.S.P. de, Fonseca, O.P., Guimaraes Junior, R. 2010. Teores de hemiceluloses, celulose e lignina em plantas de cobertura com potencial para sistema plantio direto no Cerrado. Planaltina, DF: Embrapa Cerrados, 15 p. (Boletim de Pesquisa e Desenvolvimento https://ainfo.cnptia.embrapa.br/digital/bitstream/item/75878/1/b olpd-290.pdf (accessed on: May 31 2021)

Cassán, F., Perrig, D., Sgroy, V., Masciarelli, O., Penna, C., Luna. V. 2009. Azospirillum brasilense Az39 and Bradyrhizobium japonicum E109 promote seed germination and early seedling growth, independently or co-inoculated in maize (Zea mays L.) and soybean (Glycine $\max$ L.). European Journal of Soil Biology, 45(1), 28-35. DOI: https://doi.org/10.1016/j.ejsobi.2008.08.005

Coelho, A.M., Waquil, J.M., Karam, D., Casela, C.R., Ribas, P.M. 2002. Seja o doutor do seu sorgo. Potafos, Sete Lagoas, MG. 24 p. (Arquivo do Agrônomo https://www.npct.com.br/npctweb/npct.nsf/article/BRS3150/\$File/Sorgo.pdf (accessed May 31, 2021)

Crusciol, C.A.C., Mateus, G.P., Pariz, C.M., Borghi, E., Costa. C., Silveira, J.P.F., 2011. Nutrição e produtividade de híbridos de sorgo granífero de ciclos contrastantes consorciados com capimmarandu. Pesquisa Agropecuária Brasileira, 46(10), 1234-1240. DOI: https://doi.org/10.1590/S0100-204X2011001000017

Degaspari, I.A.M., Soares, J.R., Montezano, Z.F., Del Grosso, S.J., Vitti, A.C., Rossetto, R., Cantarella, H. 2020. Nitrogen sources and application rates affect emissions of $\mathrm{N}_{2} \mathrm{O}$ and $\mathrm{NH}_{3}$ in sugarcane. Nutrient Cycling in Agroecosystems, 116(3), 329-344. DOI: https://doi.org/10.1007/s 10705-019-10045-w

EMBRAPA. EMPRESA BRASILEIRA DE PESQUISA AGROPECUÁRIA. Manual de métodos de análise de solos. 1997. Centro Nacional de Pesquisa de Solos. second ed. Embrapa, Rio de Janeiro. https://www.embrapa.br/busca-depublicacoes/-/publicacao/330804/manual-de-metodos-deanalise-de-solo (accessed May 31, 2021)

Farinelli, R. and Lemos, L.B. 2010. Produtividade e eficiência agronômica do milho em função da adubação nitrogenada e manejos do solo. Revista Brasileira de Milho e Sorgo, 9(2), 135146. DOI: https://doi.org/10.18512/1980-6477/rbms.v9n2p 135146 
Ferreira. D.F. 2019. SISVAR: a computer analv sis sv stem tofixed effects split-plot ty pe designs. Revista Brasileira de Biometria, 37(4), 529-535. DOI: https://doi.org/10.28951/rbb.v37i4.450

Freitas, R.S., Borges, W.L.B., Ticelli, M. 2014. Sorgo GraníferoDesempenho Agronômico de Cultivares. Pesquisa \& Tecnologia, 11(1), 1-6. http://www.aptaregional.sp.gov.br/acesse-os-artigospesquisa-e-tecnologia/2014/janeiro-junho/1536-sorgo-graniferodesempenho-agronomico-de-cultivares/file.html (accessed May $31,2021)$

Tahir, S.; M arschner, P. 2017. Clay addition to sandy soil reduces nutrient leaching - effect of clav concentration and ped size. Communications in Soil Science and Plant Analysis, 48(15), 1813-1821. DOI: https://doi.org/10.1080/00103624.2017.1395454

Hungria, M. 2011. Inoculação com Azospirillum brasilense: inovação em rendimento a baixo custo. Londrina: Embrapa Soja, 36 p. (Documentos 325). https://www.embrapa.br/busca-depublicacoes/-/publicacao/879471/inoculacao-com-azospirillumbrasilense-inovacao-em-rendimento-a-baixo-custo (accessedMay 31, 2021)

Liu. S.. Wang, X., Yin, X., Savoy, H.J., McClure, A., Essington, M.E. 2019. Ammonia Volatilization Loss and Corn Nitrogen Nutrition and Productivity with Efficiency Enhanced UAN and Urea under No-tillage. Scientific Reports, 9(6610), 1-12. DOI: https://doi.org/10.1038/s41598-019-42912-5

Longhini, V.Z., Souza, W.C.R. de, Andreotti, M., Soares, N.deÁ., Costa. N.R. 2016. Inoculation of diazotrophic bacteria andnitrogen fertilization in topdressing in irrigated corn. Revista Caatinga, 29(29), 338-347. DOI: https://doi.org/10.1590/198321252016v29n210rc

Lorensini, F., Ceretta, C.A., Brunetto, G., Cerini, J.B., Lourenzi, C.R., Conti, L. de, Tiecher, T.L., Schapanski, D.E. 2014 Disponibilidade de nitrogênio de fontes minerais e orgânicas ap licadas em um Argissolo cultivado com videira. Revista Ceres, 61(2), 241-247. DOI: https://doi.org/10.1590/S0034737X2014000200012

Lorensini. F.. Ceretta. C.A.. Girotto. E.. Cerini. J.B..Lourenzi.C.R. de, Conti, L., Trindade M.M. de, Melo, G.W., Brunetto, G. 2012. Lixiviation and volatilization of nitrogen in Sandy TypicHapludalf soil cultivated with grapevine submitted to the nitrogen fertilization. Ciência Rural, 42(7), 1173-1179. DOI: https://doi.org/10.1590/S0103-84782012005000038

Ma, B.L., Wu, T.Y., Tremblay, N., Deen, W., Mclaughlin, N.B., Morrison M. J., Stewart, G. 2010. On-farm assessment of the amount and timing of nitrogen fertilizer on ammonia volatilization. Agronomy Journal, 102(1), 134-144. DOI: https://doi.org/10.2134/agronj2009.0021

Macêdo, A.J.S., Ramos, J.P. F., Santos, E.M., Sousa, W.H., Oliveira, F.G. de, Souza, J.T.A., Oresca, D. 2018 Morphometric and productive characteristics of sorghum genoty pes for forage production in the brazilian semi-arid. Revista Brasileira de Saúdee Produção Animal, 9(3), 256-267. DOI: http://dx.doi.org/10.1590/s1519-99402018000300003

Magalhães, P.C., Souza, T.C. de, Schaffert, R.E. 2015. Ecofisiologia, in: Rodrigues, J.A.S. (Ed.). Cultivo do sorgo. Embrapa Milho e Sorgo. Sete Lagoas. (Sistemas de produção, 2). https://www.spo.cnptia.embrapa.br/conteudo?p_p_id=conteudopo
rtlet_WAR_sistemasdeproducaolf6_1ga1ceportlet\&p_p_lifecycle $=0 \& p \_p \_s t a t e=$ normal $\&$ p_p_mode $=$ view $\&$ p_p_col_id=column1\&p_p_col_count=1\&p_r_p_76293187_sistemaProducaold=83 01\&p_r_p_-996514994_topicoId=9203 (accessed February 12, 2020).

Mascarenhas, H.A.A., Esteves, J.A.F., Wutke, E.B., Leão, P.C.L. 2011. Nitrogênio residual da soja na produtividade de gramíneas e do algodão. Nucleus, 2(2), 5-34. DOI: http://dx.doi.org/ 10.3738/1982.2278.642

Mateus, G.P., Crusciol, C.A.C., Borghi, E., Pariz, C.M., Costa, C., Silveira, J.P.F. 2011. Adubação nitrogenada de sorgo granífero consorciado com capim em sistema de plantio direto. Pesquisa Agropecuária Brasileira, 46(10), 1161-1169. DOI: https://doi.org/10.1590/S0100-204X2011001000007

Molina, L.R., Gonçalves, L.C., Rodriguez, N.M., Rodrigues, J.A.S., Ferreira, J.J., Ferreira, V.C.P. 2000. Avaliação agronômica de seis híbridos de sorgo [Sorghum bicolor (L.) Moench]. Arquivo Brasileiro de Medicina Veterinária e Zootecnia, 52(4), 385-390. https://doi.org/10.1590/S0102-09352000000400017

Nakao, A.H., Andreotti, M., Soares, D. de A., Modesto, V.C., Dickmann, L. 2018. Intercropping Urochloa brizantha and sorghum inoculated with Azospirillum brasilense for silage. Revista Ciência Agronômica, 49(3), 501-511. DOI: https://doi.org/10.5935/1806-6690.20180057

Nascimento, C.A.C.D., Vitti, G.C., Faria, L.D.A., Luz, P.H.C., Mendes, F.L. 2013. Ammonia volatilization from coated urea forms. Revista Brasileira de Ciência do Solo, 37(4), 1057-1063. DOI: https://doi.org/10.1590/S010006832013000400022

Odhiambo, J.J.O. 2010. Decomposition and nitrogen release by green manure legume residues in different soil types. African Journal of Agricultural Research, 5(1), 090-096. DOI: https://doi.org/10.5897/AJAR09.489

Ona, O., Smets, I., Gysegom, P., Bernaerts, K., Van Impe, J., Prinsen, E., Vanderleyden, J. 2003. The effect of $\mathrm{pH}$ on indole-3-acetic acid (IAA) biosynthesis of Azospirillum brasilense sp7. Symbiosis, 35(1-3), 199-208. https://dalspace.library.dal.ca/bitstream/handle/10222/78007/ VOLUME\%2035NUMBERS\%201-3-2003-

PAGE\%20199.pdf?isAllowed=y \&sequence $=1$ (accessed May 31, 2021)

Pereira Filho, I.A. Rodrigues, J.A.S. 2015. Sorgo: o produtor pergunta, a Embrapa responde. Embrapa, Brasília. (Coleção 500 perguntas, 500 respostas). https://www.embrapa.br/buscade-publicacoes/-/publicacao/1019313/sorgo-o-produtorpergunta-a-embrapa-responde (accessed May 31, 2021)

Raij, B.V., Andrade, J.C., Cantarella, H., Quaggio, J.A. 2001. Análise química para avaliação da fertilidade de solos tropicais. Instituto Agronômico de Campinas, Campinas. http://www.iac.sp.gov.br/Publicacoes/arquivos/Raij_et_al_200 1_Metod_Anal_IAC.pdf (accessed on: May 31 2021)

Resende, A.V., Coelho, A.M., Rodrigues, J.A.S., Santos, F.C. dos. 2009. Adubação maximiza o potencial produtivo do sorgo, Embrapa Milho e Sorgo. (Circular técnica 119). https://www.infoteca.cnptia.embrapa.br/infoteca/handle/doc/6 58637 (accessed May 31, 2021) 
Rochette P.. Angers D.A.. Chantignv M.H.. Gasser. M.O.. MacDonald J.D., Pelster D.E., Bertrand N. 2013. Ammonia volatilization and nitrogen retention: how deep to incorporate urea?. Journal of Environmental Quality, 42(6), 1635-1642. DOI: https://doi.org/10.2134/jeq2013.05.0192

Rochette, P., Macdonald, J.D., Angers, D., Chantini, M.H., Gasser, M., Bertrand, N. 2009. Banding urea increased ammonia volatilization in a dry acidic soil. Journal of Environmental Quality, 38(4), 1383-1390. DOI: https://doi.org/10.2134/jeq2008.0295

Sanz-Cobena, A., Sánchez-Martín, L., García-Torres, L., Vallejo, A. 2012. Gaseous emissions of $\mathrm{N}_{2} \mathrm{O}$ and $\mathrm{NO}$ and $\mathrm{NO}_{3}{ }^{-}$ leaching from urea applied with urease and nitrification inhibitors to a maize (Zea mays) crop. Agriculture, Ecosystems \&. Environment, 149(3/4), 64-73. DOI: https://doi.org/10.1016/j.agee.2011.12.016

Santos, H.G., Jacomine, P.K.T., Anjos, L.H.C., Oliveira, V.A., Lumbreras, J.F., Coelho, M.R., Almeida, J.A., Araujo Filho, J.C., Oliveira, J.B., Cunha, T.J.F. 2018. Sistema Brasileiro de Classificação de Solos. Embrapa, Brasília. https://www.embrapa.br/solos/sibcs (accessed May 31, 2021)
Silva, D.F., Pegoraro, R.F., Maia, V.M., Kondo, M.K., Souza, G.L.O.G., Mota, M.F.C. 2017. Volatilização de amônia do solo após doses de ureia com inibidores de urease e de nitrificação na cultura do abacaxi. Revista Ceres, 64(3), 327-335. DOI: https://doi.org/10.1590/0034-737x201764030014

Soares. T. de M.. Coelho. F.S. Oliveira. V.B. de. Pontes. O., Pavinato, P.S. 2020. Soil nitrogen dynamics under tobacco with different fertilizer management in southern Brazil. Geoderma Regional, 21(e0282), 1-11. DOI: https://doi.org/10.1016/j.geodrs.2020.e00282

Tasca, F.A., Ernani, P.R., Rogeri, D.A., Gatiboni, L.C., Cassol, P.C. 2011. Volatilização de amônia do solo após a aplicação de ureia convencional ou com inibidor de urease. Revista Brasileira de Ciência do Solo, 35(2), 493-502. DOI: https://doi.org/10.1590/S0100-06832011000200018

Veras, M.S., Ramos, M.L.G., Oliveira, D.N.S., Figueiredo, C.C., Carvalho, A.M., Pulrolnik, K., Souza. K.W. 2016. Cover Crops and Nitrogen Fertilization Effects on Nitrogen Soil Fractions under Corn Cultivation in a No-Tillage System. Revista Brasileira de Ciência do Solo, 40(e0150092), 1-12. DOI: http://dx.doi.org/10.1590/18069657rbcs20150092 